Specialists, Administrators, and Benefactors', will be fully activated as soon as the 4th ICEF Proceedings book is finally out of the President's hands fairly early in 1991. Compiled principally by the President's Personal Assistant but under his direction and editorship, this propitious work of reference is to contain the authorized, suitably-detailed biographies of up to about 3,000 leaders in the fields concerned, the final choice of those to be invited to participate being made or at least sanctioned by the Foundation's confidential Awards Committee. Towards this the Foundation has the active collaboration, among other bodies, of the two principal world ones, namely UNEP and IUCN, who between them have already submitted lists totalling some 1,500 suggestions - to which another 1,000 or more will probably be added from our files dating back to the beginnings of the Environmental Movement in the mid-1960s. However, to do the job as thoroughly as is planned and surely deserved, will require considerably more funding than is yet available.

H. World Clean Energy Conferences:- In the manner of our nominal (without any financial commitment) sponsorship of the International Conferences on Waste Minimization and Clean Technology (see our report on the first in Environmental Conservation, 16(4), pp. 374-5, 1989), it is hoped* that our 1991 AGM will sanction our sponsorship 'in kind', alongside the World Meteorological Organization, of this emphasis on a much-needed world movement for clean energy. Following conferences on the use of hydrogen as a vector of solar energy and on energy compatability, the first conference under the above title is to take place in the Geneva International Conference Centre during 4-7 November 1991. The organizers who request our sponsorship are the Cercle Mondial du Consensus (CMDC), Kellerweg 38, 8055 Zürich, Switzerland, whose moving spirit and President is Engineer Gustav R. Grob.

I. Round-up Seminars:- When a major conference or congress brings together world leaders in an important field of public interest and concern in the manner of the recent Second World Climate Conference, in Geneva, it seems an excellent idea to prevail on a chosen few of those leaders to address the local public as was arranged by $\mathrm{Mr}$ J. David Laughton, the Conferences \& Meetings officer on our Journal. So we gladly acceded to his request to co-sponsor nominally and co-chair such a seminar following the scientific part of the Second World

* and was duly confirmed at the Meeting.
Climate Conference - as it is to be hoped the Foundation will approve in retrospect at its 16th AGM* $^{*}$ and likewise for future encouragement when and where appropriate. Subsequently Mr Laughton deputized for us at the Ministerial Meetings part of the Second World Climate Conference, and earlier he had organized the successful Fourth Wright Science Colloquium on 'The Evolution and Demolition of Planet Earth', which we felt 'could well be taken as the prototype of comparable occasions elsewhere and ultimately world-wide' (Environmental Conservation, 17(3), pp. 281-2, illustr., 1990).

J. Vernadsky International Centre for Biosphere Studies:- Our expressed hopes that this will embrace also the Vernadsky Foundation (described in our Summer issue of 1990) seem destined for disappointment; nor did the planning meeting take place as expected during the year under review. However, we are due to spend several days in Leningrad or Moscow or nearby Pushchino early in June 1991, to deliberate collectively on the situation regarding the Centre and Foundation and plan for their future, trusting there will be no further postponement of these overdue considerations.

K. Peace with the Environment:- There being much support for this theme and our suggestion of a Nobel Peace Prize to recognize it, we started working late in 1990 on a further nomination for 1991 (deadline for receipt in Oslo, Norway, February 1st) and came out with a joint one (by Lord Shackleton and Professor Christopher D. Stone) of UNEP and its Executive Director. This was widely favoured and supported by letters etc. from prominent people whom we contacted and who mostly responded with gratifying enthusiasm.

L. Hope for The Biosphere:- This would seem most likely to accrue from the evolution of a pandominant race or cult of Mankind that would place the interests of, and actions for, the environment before all personal and selfish ones - a theme that we started developing publicly in the year of this report, and intend to go on pursuing in future.

\section{NiCHOLAS POLUNIN \\ Foundation for Environmental Conservation \\ 7 Chemin Taverney (7th \& 8th floors) 1218 Grand-Saconnex Geneva, Switzerland.}

* This was duly confirmed at the Meeting.

\title{
Hooke Park College to Encourage Small Timber-based Rural Industries
}

Industry has increasingly used 'new materials' made from finite resources, but timber remains the world's major renewable resource and the most energy-efficient structural material. Recognition of the multiple role of trees in the environment has never been so acute as it is today. Given that Britain has an ideal climate for growing excellent timbers, the available land, the design and technological expertise, and a great tradition for furniture and building, the essential ingredients are there for a network of small industries which make efficient use of our indigenous timber supplies and those coming on stream in the years ahead.

At present, $10 \%$ of the land in the UK (or some 2 mil- lion hectares) is used for timber-growing. The extensive clearance of the forests in Britain over the past five centuries has led to a shift in production of wooden items from the countryside to the ports, with their ready access to foreign timber and, increasingly, to imported manufactured products. The decline of manufacturing in the countryside has so reduced the market for indigenous timber that woodlands in this country have become a liability, mainly acceptable because of increased interest in their contribution to the landscape and to Nature conservation. In order to justify the reintroduction of management that will produce high-quality timber, however, it is crucial to maximize the value of timber by processing. 


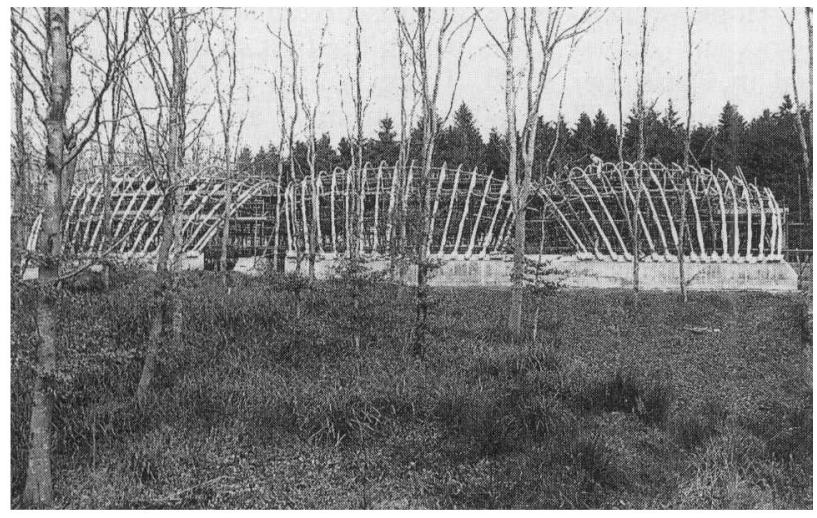

FIG. 1. The training workshops of Hooke Park College, Dorset, are made up on three vaulted modules. Thinnings from Hooke Park are being bent and joined to form an arch, and are subsequently braced laterally to form a shell structure as indicated in this photograph taken during construction.

\section{Great Diversity of Timber}

Unlike most commodities, timber is infinitely diverse in type, quality, and size. Parcels of high-quality mature trees can command standing prices of $£ 30-£ 150$ a tonne. In ideal circumstances, there might be 350 such trees to the hectare; in other words, a tax-free capital sum of $£ 37,500$ a hectare would be the reward for 100 years of consistent management. In order to reach that stage, some $90 \%$ of the trees originally planted would have been removed as thinnings in order to give more space for selected trees to develop their canopy and their girth. These thinnings, which represent $50 \%$ of the annually available crop, commonly have a standing value of £3-£5 a tonne after 30 years, whether they are going to be sold for pulp, pallet timber, or for firewood.

A standing value of $£ 5$ a tonne for timber which has taken 30 years to grow is a poor return indeed. However, as soon as the grower processes the commodity into a condition which is closer to the needs of the market, there is scope to increase the turnover significantly and to generate a profit at least on that operation. Felled, cut to length, and stacked at the roadside, timber from 7.5-25 $\mathrm{cm}$ in diameter commands a price of $£ 20$ to $£ 25$ per tonne. However, the value of the timber in some of the downstream markets is much higher, with fencing at $£ 40-£ 60$ a tonne, planking at $£ 100$ a tonne, particle board and paper at $£ 250$ a tonne, joinery at $£ 500$ a tonne, and furniture products ranging widely from $£ 2,500$ to $£ 25,000$ a tonne - all at wholesale prices to the retail trade.

Official policies in the UK have encouraged the extensive planting of timber without proper regard for quality in the selection of seed, silvicultural management, or the development of markets in construction and domestic products. The relative values of such products make it clear that timber-growing needs to be accompanied by manufacturing industries which utilize the resource and market the products.

\section{The Parnham Trust}

The undersigned, Director of the Parnham Trust, runs his own internationally recognized fine furniture business from his stately home, Parnham House, in West
Dorset, England, UK. The John Makepeace Workshop specializes in the use of sustainable English hardwoods. Makepeace furniture can be found in private and public collections around the world. The undersigned bought Parnham House in 1976 and a year later established the independent School for Craftsmen in Wood for the purpose of giving young would-be entrepreneurs an integrated training in design, fine craftsmanship, and business management. In 1983 The Parnham Trust, which runs the school at Parnham, bought 350 acres (c. 143 ha) of mixed woodland from the British Forestry Commission in order to establish Hooke Park College for research, development, and teaching of ways of using neglected resources of small-dimension, low-value, indigenous timber in larger-scale manufacturing enterprises.

The challenge facing The Parnham Trust required collaboration among a number of disciplines. Working together, scientists, engineers, chemists, designers, foresters, and building contractors, have evolved different systems for the construction of the buildings to accommodate Hooke Park College, using the thinnings from the surrounding 30-years-old woodland. Trees from 6 to $24 \mathrm{~cm}$ in diameter form all of the structural components for systems of housing and industrial workshops in the College - in place of sawn material from mature trees of twice that age (Figs 1 and 2).

\section{Course in Manufacturing}

The course at Hooke Park College has six components which are integrated in practice: (1) woodland management and timber technology - to establish an understanding of the material; (2) design - to resolve the technical, aesthetic, and commercial, requirements; (3) product development - to refine the design against the various criteria; (4) production - a practical training in the machine processes; (5) computers - in design, machine

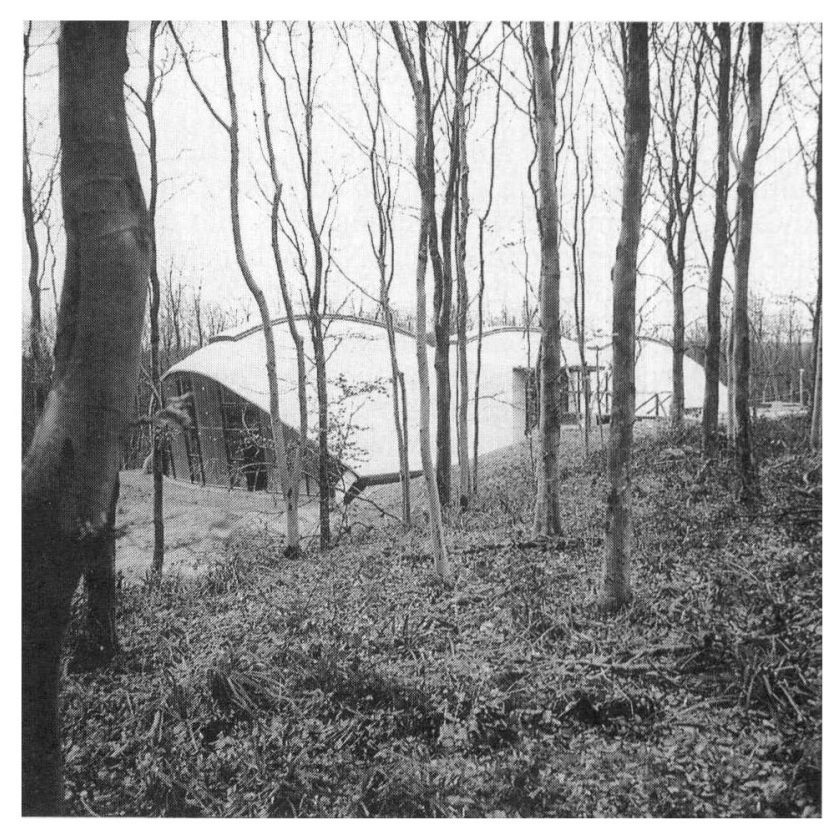

FIG. 2. The training centre built from spruce thinnings removed from Hooke Park during forest management. 
control, and business management; and (6) enterprise development - to generate an operational business plan.

To date, we have received magnificent help from the British Government, the private sector, companies, trusts, and individuals. Just under half of the $£ 2.5$ millions necessary has already been received or promised. Donors include government agencies such as the Countryside Commission and the Forestry Commission, and large companies such as BP and Legal \& General.

By showing that the produce can be utilized in production, and at the same time improving the quality of the remaining crop, we aspire to encourage others to follow suit. By converting as much of some 750 tonnes of timber annually - harvested from the woodland at Hooke Park - into buildings and consumer products, we are seeking to show how commercial enterprise linked to timber-growing can promote improved standards of resource management, generate local employment, and substitute for imports.
Hooke Park College offers twelve places a year on its two-years' course, from which the first students graduated in December 1990. There is also a programme of short courses. The College buildings are revolutionary structures constructed from thinnings taken from the surrounding forest. They serve as striking models of the Hooke Park philosophy, bear witness to a project of world-wide significance seeking international support, and offer prospects of an exciting future for the woodlands of tomorrow.

JoHN MAKEPEACE, OBE, Director*
The Parnham Trist
Parnham House
Beaminster
Dorset DT8 $3 N A$
England, UK.

* For visits or application forms, please telephone Mrs Margaret McMullen, Administrator, (0308) 862204, or write to same address.

\section{'Men of The Trees' in Western Australia}

\section{Introduction}

'Men of The Trees' in Western Australia is alive and well! So much so, in fact, that it is 'bursting at the seams' with projects, ideas, and a vision of the future - "enough to take your breath away'.

The Western Australian branch of Men of The Trees was founded in 1979 , shortly after a visit to Perth of Richard St Barbe Baker*, by Charles Peaty. Peaty went on to establish branches of Men of The Trees in all the other states of Australia, but Western Australia is one of the most active branches.

In the manner of most societies, the branch founded by Charles Peaty started tenuously, with a small membership; but in the last eleven years its membership has grown to almost 1,000. About one-quarter of these members are scattered around the countryside in Western Australia and the remainder live in the suburbs of Perth. A point worth noting is that, with only two exceptions, none of the members are professional foresters or horticulturists - we are a group of amateurs, all working towards a common goal of getting trees into the ground and seeing our environment and Nature benefit accordingly. We are a 'doing' group, 'with a spade in our hands and mud on our boots.'

\section{Give-away Plantings of Seedlings}

The range of activities in which Men of The Trees get involved is wide and varied. The focal point of its operations is a tree-seedling nursery called ' $S t$ Barbe Grove' situated 18 kilometres north-east of Perth where, on leased land, Men of The Trees established a nursery in 1987. After a tentative start with rather primitive facilities, the operation has grown to the extent that now almost 200,000 seedlings are reared annually from seed. The nursery is now well equipped with tunnel houses in which the seed is propagated, a sprinkler system, and steel trestles on which the tiny seedlings are placed in trays to grow. A nursery manager's office is the nervecentre of the nursery.

* See the illustrated account of 'St Barbe Baker, Far-sighted Pioneer', by James M. Fitzwilliams, published in Environmental Conservation, Vol. 14, No 2, pp. 164-8, 1987. —Ed.
Most seedlings are of native species - eucalypts, acacias, melaleucas, and callistemons, to name the most common - particularly those which we have found the easiest to propagate and to thrive best in the dry climate here. Carobs, tagasaste, and a few oaks, are also grown, and all these are destined to be planted either in country areas or around the city. During the winter months plantings are scheduled for every weekend. These are either on public or shire land $\dagger$ in a country town, or perhaps in one of the numerous parks and reserves in the city, all of which are 'crying out' for more trees. A coordinator supervises the entire planting, being responsible for ensuring that sufficient people turn up to plant, and also that the seedlings get to the planting fully viable and in a suitable state. For this we have a trailer capable of carrying 4,000 seedlings at a time. We do not charge for the seedlings which we grow and plant - we only give them away, merely asking for a donation to help to defray costs.

\section{Arbor Day and 'Children of The Trees'}

Another activity in which Men of The Trees takes a leading role is on Arbor Day every June, when the growing of seedlings by a city school - for planting in the country in conjunction with a school situated there culminates in a grand planting at a country centre.

In this and other ways there is quite a close involvement by Men of The Trees with schools, and we are constantly addressing school groups, spreading the message about trees among the young. Last year a "Children of The Trees' group was started to encourage interest in trees among children, and their first major project was to visit an Aboriginal reserve, 450 kilometres north-east of Perth, for a week of tree planting. During school vacations these children always have some activity going on at St Barbe Grove.

We restrict our planting to public or shire land, the only exception being that on selected farms, where the farmer allocates to us two hectares of his land as an experimental plot, we plant fodder and nut trees. This year we have started a 'Farm Tree Help Scheme' whereby a gro-

$\uparrow$ Signifying, in Australia, land in a rural area having its own elected council. - Ed. 